\title{
MENINGKATKAN PEMAHAMAN KEWIRAUSAHAAN DAN LITERASI KEUANGAN PADA KOPERASI DESMIGRAF DI DESA LONTAR KECAMATAN TIRTAYASA KABUPATEN SERANG PROVINSI BANTEN
}

\author{
Desmintari $^{1}$ dan Lina Aryani ${ }^{2}$ \\ ${ }^{1}$ Jurusan Ilmu Ekonomi, FEB UPN Veteran Jakarta \\ Email: desmintari@upnvj.ac.idf \\ ${ }^{2}$ Jurusan Manajemen FEB UPN Veteran Jakarta \\ Email: linaaryani@upnvj.ac.id
}

\begin{abstract}
The economic activity of Lontar Village, Serang Regency is developing based on the economic potential of the sea, most of which are fishermen. In general, the people of Lontar Village in facing harvest do not want the harvest to be processed first to add added value. But at this time seaweed is processed into various kinds of snacks with seaweed as basic ingredients. Processed business is carried out by two Cooperatives and fourteen Joint Business Groups. Even though business institutions have been established, there are several problems, including people who not understand the problems of entrepreneurship, lack of financial literacy in managing cooperative organizations and Joint Business Groups, and the absence of institutions that come to Lontar Village to provide input on entrepreneurship and financial literacy. The purpose of this service activity is to add insight into entrepreneurship and financial literacy for the management and members of the cooperative. This service method uses socialization, discussion, and evaluation through counseling. The results of this service are the effect of counseling on knowledge about entrepreneurship and financial literacy, as well as an increase in the knowledge of the management and members after counseling from the knowledge aspects of entrepreneurship and financial literacy. Activities to increase skills and empowerment for all management and members of cooperatives need to be held further. Also, there is a need for sustainable assistance and synergy between academics and practitioners related to strengthening cooperative governance and institutions. Keywords: entrepreneurship, cooperatives, financial literacy
\end{abstract}

\begin{abstract}
ABSTRAK
Kegiatan perekonomian Desa Lontar Kabupaten Serang berkembang berbasiskan potensi ekonomi dari laut yang sebagian besar sebagai nelayan. Pada umumnya masyarakat Desa Lontar dalam menghadapi panen tidak mau hasil panen diolah dahulu untuk menambah nilai tambah. Namun pada saat ini rumput laut diolah menjadi berbagai macam jajanan dengan bahan dasar rumput laut. Usaha olahan dilakukan oleh dua Koperasi dan empat belas Kelompok Usaha Bersama (KUB). Meskipun lembaga usaha telah didirikan, namun adanya beberapa permasalahan diantaranya masyarakat yang kurang memahami masalah koperasi dan kewirausahaan, minimnya literasi keuangan dalam mengelola organisasi koperasi dan KUB, serta belum adanya institusi yang turun ke Desa Lontar untuk memberikan masukan tentang koperasi, kewirausahaan dan literasi keuangan. Tujuan kegiatan pengabdian ini adalah untuk menambah wawasan mengenai kewiraushaan dan literasi keuangan pengurus dan anggota koperasi. Metode pengabdian ini menggunakan sosialiasi, diskusi, dan evaluasi melalui penyuluhan. Hasil dari pengabdian ini adalah adanya pengaruh penyuluhan terhadap pengetahuan tentang kewirausahaan dan literasi keuangan, serta adanya peningkatan pengetahuan pengurus dan anggota koperasi setelah adanya penyuluhan dari aspek pengetahuan kewirausahaan dan literasi keuangan. Kegiatan peningkatan skill dan empowerment pada seluruh pengurus dan anggota koperasi perlu diadakan lebih lanjut. Serta, perlu adanya pendampingan secara berkelanjutan dan sinergitas antara akademisi dan praktisi terkait penguatan tata kelola dan kelembagaan koperasi.
\end{abstract}

Kata Kunci: kewirausahaan, koperasi, literasi keuangan

\section{PENDAHULUAN}

\section{Analisis Situasi}

Desa Lontar merupakan salah satu Desa di kecamatan Tirtayasa yang berada di pesisir utara Kabupaten Serang berbatasan langsung dengan laut Jawa dengan memiliki cukup potensi perikanan khususnya di bidang budidaya rumput laut. Luas wilayah desa Lontar adalah 556,5 Ha atau sekitar 10,115 dari seluruh wilayah di kecamatan Tirtayasa yang secara geografis berbatasan 
dengan sebelah timur desa Tengkurak, sebelah barat desa Susukan, sebelah selatan desa Alangalang dan sebelah utara Laut Jawa (Peraturan Daerah Kabupaten Serang, 2013).

Kegiatan perekonomian di Desa Lontar berkembang berbasiskan potensi ekonomi dari laut yang sebagaian besar sebagai nelayan. Kegiatan utamanya adalah budidya rumput laut yang dimulai pada tahun 2010 yang menunjukan perbaikan kesejahteraan bagi petani rumput laut. Pada umumnya masyarakat Desa Lontar dalam menghadapi panen tidak mau hasil panen diolah dulu untuk menambah nilai tambah (Value Added), namun setelah dikeringkan dijual di para pengepul atau tengkulak. Namun pada saat ini rumput laut diolah menjadi berbagai macam jajanan dengan bahan dasar, usaha olahan dilakukan oleh 2 Koperasi dan 14 kelompok Usaha Bersama (KUB) antara lain KUB sebagai pelopor adalah KUB Bahari Jaya di RT 02 RW 08 yang dengan ketua Bpk. Yanto Sugianto dan KUB Mitra Bahari Ainun Food berlokasi di RT 012 RW 03 Desa Lontar. Namun dengan tidak adanya pemahaman kebersamaan dan bimbingan serta penyuluhan, koperasi dan KUB tidak berjalan dengan sebagaimana mestinya.

Berdasarkan Tabel 1 dapat dilihat dari segi sosial jumlah penduduk 6.998, laki-laki sejumlah 3.459, perempuan 3.539, penduduk pendatang 129 dan penduduk pergi 52 orang yang menggambarkan jumlah antara laki-laki dan perempuan seimbang sehingga dimana sebagaian penduduk perempuan membantu usaha dari kepala keluarga. Namun bila dilihat dari kondisi sejahtera dimana hampir 50\% adalah keluarga Pra Sejahtera, dibandingkan dengan keluarga sejahtera III yang jumlahnya $78 \mathrm{KK}$, memperlihatkan tingkat kesejahteraan masyarakat Desa Lontar masih dikatakan jauh dari jangkauan sejahtera. Juga dilihat dari pendidikan sebagaian besar putus sekolah sejumlah 729 orang dan buta huruf sejumlah 526 orang.

Tim pengabdian kepada masyarakat Universitas Pembangunan Nasional Veteran Jakarta aka memberikan upaya guna peningkatan pengetahuan mengenai koperasi dan Kelompok Usaha Bersama yang sebagian dari anggotanya adalah berpendidikan SD/MI, warga yang putus sekolah dan buta huruf tentang perkoperasian sebagaimana mestinya dan pencatatan keuangan yang lebih baik, dimana banyak yang belum mengerti secara teoritis dan praktek tentang operasional organisasi atau lembaga koperasi dan Kelompok Usaha Bersama serta masalah pencatatan keuangan yang tidak harus diketahui oleh pengurus saja tetapi juga harus diketahui oleh anggota koperasi maupun Kelompok Usaha Bersama. Data banyaknya lembaga usaha Desa Lontar dapat dilihat pada Tabel 2 .

Berdasarkan Table 2, Kelompok Usaha bersama (KUB) memiliki jumlah paling banyak diantara lembaga usaha lainnya. Upaya dalam memahami permasalahan mitra, tim pengabdi dari Universitas Pembangunan Nasional Veteran Jakarta hendak memberikan pengenalan dan sosialisasi tentang kewirausahaan, per koperasian dan tentang literasi pencatatan keuangan pada pengurus dan anggota koperasi serta Kelompok Usaha Bersama yang berada di wilayah Desa Lontar Kecamatan Tirtayasa Kabupaten Serang-Banten. 


\section{Tabel 1}

\begin{tabular}{lll}
\multicolumn{2}{l}{ Kondisi Sosial Masyarakat } & \\
\hline NO. & Keterangan & Jumlah \\
\hline 1. & Kepala Keluarga & $1.837 \mathrm{KK}$ \\
2. & Keluarga Pra Sejahtera & $878 \mathrm{KK}$ \\
3. & Keluarga Sejahtera I & $658 \mathrm{KK}$ \\
4. & Keluarga Sejahtera II & $223 \mathrm{KK}$ \\
5. & Keluarga Sejahtera III & $78 \mathrm{KK}$ \\
\hline
\end{tabular}

\section{Tabel 2}

Lembaga Kelompok Usaha Desa Lontar

\begin{tabular}{clc}
\hline No. & \multicolumn{1}{c}{ Lembaga Usaha } & Jumlah \\
\hline 1. & Koperasi & 2 Lembaga \\
2. & Kelompok Usaha bersama (KUB) & 14 Kelompok \\
3. & Lembaga Kursus & 1 Lembaga \\
4. & PJTKI & 2 Lembaga \\
5. & Bank Sampah & 1 Lembaga \\
\hline
\end{tabular}

Literasi keuangan adalah kemampuan dalam mengelola keuangan, termasuk bagaimana cara menghasilkan uang, mengelola dan menginvestasikan uang tersebut. Rendahnya pengetahuan akan literasi keuangan berpengaruh terhadap kerentanan rumah tangga dan kerugian dimasa depan (Stolper \& Walter, 2017).

Berdasarkan penelitian yang telah dilakukan bahwa adanya pelatihan mengenai literasi keuangan dapat meningkatkan kemampuan mengelola keuangan pada masyarakat (Dewi \& Munawaroh, 2019; Herawati \& Anantawkrama, 2016). Beberapa literatur telah menyatakan bahwa kemampuan perusahan dalam mengenali dan mengakses sumber daya keuangan akan berdampak pada pertumbuhan perusahaan, termasuk usaha dalam lingkup mikro (Admoko, et.al., 2016). Selain itu, secara umum literasi keuangan dapat menjaga keberlangsungan usaha dengan skala mikro (Ariwibawa, 2016). Dalam menghadapi Masyarakat Ekonomi ASEAN 2016, lembaga usaha seperti koperasi harus siap dan matang secara manajemen keuangan dan mampu bersaing.

\section{Permasalahan Mitra}

Pengurus dan anggota koperasi serta KUB di Desa Lontar, Kecamatan Tirtayasa Kabupaten Serang - Banten menghadapi beberapa permasalahan, diantaranya yaitu :

a. Masyarakat yang kurang memahami masalah koperasi dan kewirausahaan

b. Minimnya literasi keuangan dalam mengelola organisasi koperasi dan KUB.

c. Belum adanya institusi yang turun ke Desa Lontar untuk memberikan masukan tentang koperasi, kewirausahaan dan literasi keuangan.

\section{Tujuan Kegiatan PKM}

Kegiatan pengabdian kepada masyarakat memiliki tujuan sebagai berikut: 
a. Agar pegurus dan anggota koperasi memahami tentang koperasi dan jiwa usaha guna meningkatkan inovasi dan produksi.

b. Untuk memberikan tambahan literasi keuangan dan koperasi bagi pengurus dan anggota.

c. Merintis kelembagaan koperasi di Desa Lontar, Kecamatan Tirtayasa Kabupaten SerangBanten.

\section{METODE PELAKSANAAN PKM}

Kerangka Pemecahan Masalah

Bagan alir kegiatan PKM dapat dilihat pada Gambar 1.

\section{Gambar 1}

Bagan Alur Kegiatan PKM

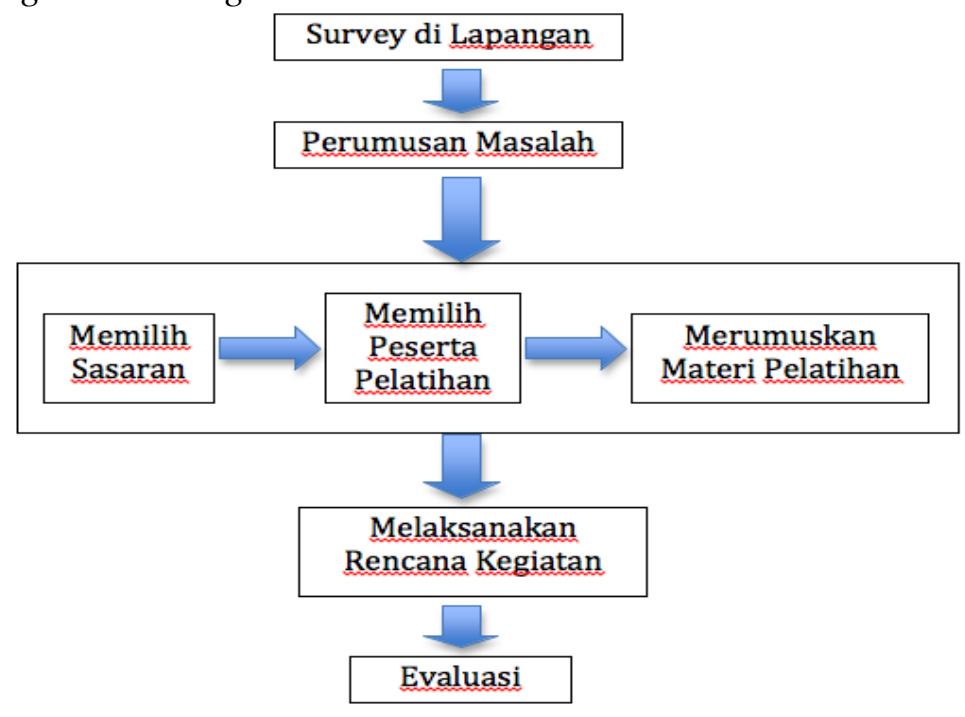

Berdasarkan analisis situasi dan survey yang dilakukan dilapangan, didapatkan rumusan masalah yaitu masih banyak masyarakat yang kurang memahami masalah koperasi dan kewirausahaan, minimnya literasi keuangan dalam mengelola organisasi koperasi dan KUB dan belum adanya institusi yang turun ke Desa Lontar untuk memberikan masukan tentang koperasi, kewirausahaan dan literasi keuangan.

\section{Khalayak Sasaran}

Pelaksanaan pengabdian pada masyarakat yang kami lakukan adalah disesuaikan dengan yang dibutuhkan dari Desa Lontar Kecamatan Tirtayasa Kabupaten Serang - Banten mengenai permasalahan dimana Koperasi dan KUB yang penanganannya belum sesuai sebagaimana mestinya, sehingga operasional dan organisasi tersebut memerlukan masukan-masukan untuk para pengurus dan anggota lebih memahami tentang kewirausahaan, koperasi dan literasi tentang pencatatan keuangan pada koperasi. 


\section{Tahap pelaksanaan PKM}

Tahap pelaksaan PKM dapat dilihat pada Tabel 3.

Tabel 3

Tahap Pelaksanaan Prosedur Kerja

\begin{tabular}{|c|c|c|}
\hline $\begin{array}{c}\text { Tahap } \\
\text { Ke }\end{array}$ & Kegiatan & Indikator \\
\hline 1. & $\begin{array}{l}\text { Memberikan sosialisasi, pemahaman } \\
\text { tentang kewirausahaan dan ekonomi }\end{array}$ & $\begin{array}{l}\text { Dilakukan Pretest dan Postest untuk menilai } \\
\text { pencapaian peningkatan pemahaman materi } \\
>75 \%\end{array}$ \\
\hline 2. & $\begin{array}{l}\text { Diskusi dan evaluasi kegiatan } \\
\text { pemasaran yang telah dilakukan saat } \\
\text { ini dan potensi kewirausahaan yang } \\
\text { belum dilakukan. }\end{array}$ & $\begin{array}{l}\text { a. Dapat mengetahui kelemahan dan kekuatan } \\
\text { pemasaran yang dilakukan saat ini. } \\
\text { b. Dapat mengetahui peluang pasar kedepan }\end{array}$ \\
\hline
\end{tabular}

Indikator yang digunakan guna mencapai solusi permasalahan yang ada dalam kegiatan ini dapat tersaji pada tabel berikut ini.

\section{Tabel 4}

Indikator Pengabdian Pada Masyarakat

\begin{tabular}{|c|c|c|c|}
\hline No. & Tujuan & Indikator & Instrumen \\
\hline 1. & $\begin{array}{l}\text { Meningkatkan literasi keuangan pada } \\
\text { koperasi dan KUB }\end{array}$ & $\begin{array}{l}\text { Pengetahuan keuangan \& } \\
\text { kemampuan pengelolaan keungan }\end{array}$ & Kuisioner \\
\hline 2. & Meningkatkan pengetahuan berkoperasi & Mengetahui arti penting koperasi & $\mathrm{Kl}$ \\
\hline 3. & Mengetahui tata cara pendirian koperasi & Memahami pendirian koperasi & Kuisioner \\
\hline
\end{tabular}

\section{Metode Pelaksanaan PKM}

Metode pelaksanaan kegiatan dalam melaksanakan solusi mengatasi permasalahan yang ada adalah sebagai berikut:

\section{a. Metode Ceramah/Sosialisasi}

Metode ini dipilih untuk memberikan penjelasan berupa pengenalan tentang koperasi dan pemahaman liretasi keuangan serta permasalahan ekonomi guna meningkatkan kesejahteraan masyarakat Desa Lontar.

b. Metode Tanya Jawab

Metode tanya jawab sangat penting bagi para peserta pelatihan, baik disaat menerima penjelasan, serta saat mempraktikkannya. Metode ini memungkinkan pengurus dan anggota koperasi dan KUB untuk menggali pengetahuan sebanyak-banyaknya tentang penerapan pencatatan keuangan dalam keberlangsungan kegiatan usaha yang dilakukan.

c. Tahap Pembuatan Laporan

Pembuatan laporan dilakukan setelah selesainya tahap seminar dan pelatihan serta pendampingan

\section{d. Tahap Seminar Hasil}

Seminar hasil dipaparkan oleh ketua atau anggota pada jadwal yang telah ditentukan oleh LPPM Universitas Pembangunan Nasional Veteran Jakarta.

\section{e. Laporan Kegiatan}

Laporan kegiatan pembinaan disusun oleh ketua dan anggota dan disampaikan kepada LPPM Universitas Pembangunan Nasional Veteran Jakarta. 


\section{HASIL DAN PEMBAHASAN}

\section{Analisis dan Pembahasan}

Hasil analisis data dari kegiatan ini dapat dilihat pada Tabel 5.

\section{Tabel 5}

Test Statistics ${ }^{a}$

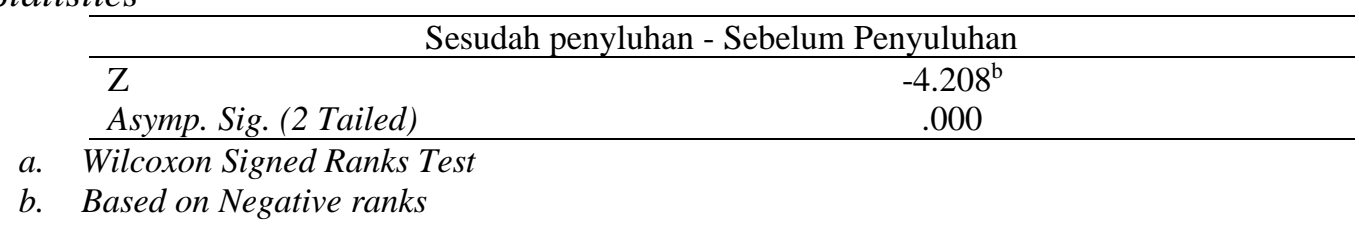

Berdasarkan tabel diatas, nilai Asymp.Sig (2-tailed) lebih kecil dari 0,05, artinya ada perbedaan antara hasil penyuluhan mengenai pemahaman kewirausahaan pada pengurus dan anggota koperasi sebelum dan sesudah penyuluhan. Hasil tersebut sejalan dengan penelitian terdahulu yang menyatakan bahwa dengan memberikan pengetahuan akan keuangan, akan meningkatkan literasi keuangan dan kewirausahaan (Setiawan, 2019; Amelia, et.al., 2018). Pentingnya pengetahuan akan literasi keuangan secara sederhana dapat meningkatkan kesadaran pelaku usaha mikro termasuk koperasi akan pentingnya informasi mengenai keuangan (Alinsari, 2021).

\section{Analisis Deskriptif Sebelum dan Sesudah Penyuluhan Koperasi}

Berdasarkan pengolahan hasil kuisioner, terdapat beberapa hasil yaitu sebanyak $34,8 \%$ pengurus koperasi dapat membuat laporan keuangan dengan terstruktur sebelum adanya penyuluhan. Hanya sebesar $26,1 \%$ yang telah membayar kewajiban simpanan wajib dan sukarela sebelum penyuluhan dan meningkat menjadi $73,9 \%$ setelah adanya penyuluhan. Terkait kewajiban membayar pinjaman tepat waktu hampir dilakukan oleh 50\% responden yang mengikuti penyuluhan koperasi setelah mengikuti penyuluhan kesadaran untuk membayar kewajiban tepat waktu meningkat menjadi $100 \%$ atau bertambah 50\%. Sebagain besar responden memahami mengenai wirausaha yaitu sebesar 78,3\%. Hal tersebut dikarenakan akses informasi dan teknologi dimiliki oleh sebagain besar responden, dan sebanyak $21,7 \%$ responden berubah perilaku dan pengetahuan akan wirausaha setelah adanya penyuluhan sehingga responden memiliki pemahaman lebih terkait wirausaha. Terdapat penemuan yang menarik dalam penelitian ini yaitu sebesar 73,9\% responden selain paham kegiatan wirausaha, tujuan wirausaha diketahui secara tajam dan jelas meskipun kegiatan penyuluhan belum dilakukan. Selanjutnya materi penyuluhan koperasi adalah etika usaha telah dimiliki oleh responden sebanyak 56,5\%. Hal tersebut menunjukkan meskipun pemahaman mengenai kegiatan menabung dan jenis menabung kecil karena jiwa wirausaha telah dimiliki, maka responden sudah mendalami dan mengikuti etika usaha sebagai aturan tidak tertulis. Selain itu, responden yang mengetahui kegiatan wirausaha bahkan sebelum kegiatan penyuluhan koperasi dilaksanakan, hanya memiliki pemahaman mengenai menabung sebesar $26,1 \%$ sedangkan $73,9 \%$ responden tidak memahami mengapa kegiatan menabung perlu dilakukan. Pemahaman terkait kelebihan melakukan kegiatan menabung tidak dimiliki oleh responden. Sebanyak 34,8\% responden tidak memahami keuntungan menabung, namun setelah kegiatan penyuluhan terjadi perubahan paradigma dan pemahaman terkait kegiatan menabung. Bermacammacam cara menabung hanya diketahui oleh $39,1 \%$ responden, hal tersebut terjadi karena terbatas akses informasi yang diperoleh akan tetapi setelah kegiatan penyuluhan dilakukan sejumlah 60,9\% responden memahami berbagai jenis cara menabung. Sejumlah besar responden tidak memahami mengenai kartu kredit dan debit dan hanya 34,8\% yang kenal dan mengetahui kartu kredit dan debit, setelah adanya penyuluhan terjadi kenaikan pemahaman sebesar 34,8\% akan informasi kartu debit dan kartu kredit. Hasil ini sesuai dengan penelitian yang menyatakan bahwa ketika masyarakat mengetahui akan fungsi dan produk perbankan, maka terdapat keinginan masyarakat 
untuk menabung di bank (Simanjuntak, Ningsih, \& Syafitri, 2019). Selain itu, produk perbankan dapat juga digunakan untuk memenuhi kebutuhan dana dalam mengembangkan usaha (Amelia et al., 2020).

\section{KESIMPULAN DAN SARAN}

Berdasarkan hasil studi lapang dan analisis pembahasan pengabdian kepada masyarakat diperoleh kesimpulan sebagai berikut:

1. Ada perbedaan antara hasil penyuluhan peningkatan pemahaman kewirausahaan pada koperasi sebelum dan sesudahnya, sehingga dapat dikatakan ada pengaruh pengetahuan mengenai koperasi, kewirausahaan dan literasi keuangan setelah dan sesudah penyuluhan.

2. Instrumen yang dijadikan tools menunjukkan adanya peningkatan pengetahuan pengurus maupun anggota koperasi mengenai kewirausahaan dan literasi keuangan setelah adanya penyuluhan yang diberikan dari berbagai aspek.

Adapun saran yang dapat kami berikan diantaranya:

1. Perlu diadakannya kegiatan-kegiatan peningkatan skill dan empowerment pada seluruh pengurus dan anggota koperasi

2. Adanya pendampingan secara berkelanjutan dan sinergitas antara akademisi dan praktisi terkait penguatan tata kelola dan kelembagaan koperasi khususnya peningkatan informasi dan akses terkait

3. Komunikasi dan informasi dengan perbankan oleh dunia usaha dan koperasi harus difasilitasi agar tagline Koperasi Keren dan UKM Naik Kelas bisa direalisasikan.

\section{Ucapan Terima Kasih (Acknowledgement)}

Ucapan terima kasih kami sampaikan kepada Ketua dan Anggota Koperasi Desmigraf Desa Lontar Kabupaten Serang-Banten dan kepada Fakultas Ekonomi dan Bisnis Universitas Pembangunan Nasional Veteran Jakarta.

\section{REFERENSI}

Admoko, S., Danso, A \& Damoah, J.O. (2016). The moderating influence of financial literacy on the relationship between access to finance and firm growth in Ghana. Ventura Capital, 18(1). 43-61.

Alinsari, N. (2021). Peningkatan literasi keuangan pada umkm melalui pelatihan dan pendampingan pembukuan sederhana. Magistrorum et Scholarium: Jurnal Pengabdian Masyarakat, 1(2), 256-268. https://doi.org/10.24246/jms.v1i22020p256-268

Amelia, Y., Gustiawaty, F., Sarumpaet, S., \& Usman, M (2018). Edukasi literasi perencanaan keuangan dan pembiayaan untuk petani dan umkm kelompok masyarakat di desa Lumbirejo. Prosiding Pengabdian Kepada Masyarakat, 155-160.

Amelia, R. W., Sari, W. I., Nofiana, L., Hidayat, A., Lutfi, A. M., \& Akbar, M. R. (2020). Strategi dalam meningkatkan literasi keuangan melalui produk perbankan untuk warga rt 006/rw 10 kampung Cimuncang, desa Karangnunggal, Tasikmalaya, Jawa Barat. Dedikasi PKM UNPAM, 1(1), 93-99.

Ariwibawa, D. (2016). Pengaruh literasi keuangan terhadap kinerja dan keberlangsungan umkm di Jawa Tengah. Siasat Bisnis, 20(1), 1-13. https://doi.org/10.1007/s10006-013-0431-4

Dewi, R. S., \& Munawaroh. (2019). Ibm literasi keuangan syariah bagi masyarakat di desa Ara Payung kecamatan Pantai Cermin. Prosiding Seminar Nasional Hasil Pengabdian, 535-538.

Herawati, N. T., \& Anantawkrama. (2016). Pelatihan Dasar-dasar keuangan untuk meningkatkan. Seminar Nasional Pengabdian Kepada Masyarakat, 108-117. 
Peraturan Daerah Kabupaten Serang. (2013). Rencana Zonasi Wilayah Pesisir dan Pulau-Pulau Kecil Kabupaten Serang tahun 2013-2033.

Setiawan, B. (2019). Pelatihan literasi keuangan generasi milenial di Palembang. Jurnal Pengabdian Sriwijaya, 7(4), 882-887. https://doi.org/10.37061/jps.v7i4.12352

Simanjuntak, J., Ningsih, D., \& Syafitri, R. (2019). Literasi keuangan masyarakat Tanjung Gundap kelurahan Tembesi kecamatan Sagulung kota Batam. Jurnal Pengabdian Kepada Masyarakat UBJ, 1(2), 41-42. http://dx.doi.org/10.32493/dedikasipkm.v1i2.6449

Stolper, O. A \& Walter, A. (2017). Financial literacy, financial advice, and financial behavior. Journal of Business Economics, 87(5), 581-643. https://doi.org/10.1007/s11573-017-0853-9

Undang-Undang Republik Indonesia Nomor 17 Tahun 2012 tentang Perkoperasian. (2012).

Indonesia. https://peraturan.bpk.go.id/Home/Details/39094/uu-no-17-tahun-2012 